\title{
PENGARUH CARA PENGERINGAN SIMPLISIA DAUN PANDAN (Pandanus amaryllifolius) TERHADAP AKTIVITAS PENANGKAL RADIKAL BEBAS DPPH (2,2-DIFENIL-1-PIKRILHIDRAZIL)
}

\section{EFFECT OF DRYING METHODS OF PANDAN LEAVES (Pandanus amaryllifolius) TOWARDS SCAVENGING FREE RADICAL ACTIVITY DPPH (2,2-DIPHENYL-1- PICRYLHYDRAZYL) METHOD}

\author{
Nera Umilia Purwanti ${ }^{1}$, Sri Luliana ${ }^{1)}$, Novita Sari ${ }^{1)}$ \\ ${ }^{1)}$ Department of Pharmacy, Tanjungpura University, West Borneo
}

\begin{abstract}
Post harvest processing plant can determine the quality of the raw materials of medicinal plants. The main factors that contribute in post harvest processing of medicinal plants is a drying method. Drying is the most important step to keep the compound stability in simplisia especially the compounds that have antioxidant activity. The objective of this research is to know the effect of drying method in gaining of antioxidant activity extract methanol Pandanus amaryllifolius leaves. The drying methods tested were oven-drying at $40^{\circ} \mathrm{C}$, direct sunlight-drying $(S M L)$, indirect sunlight-drying (SMTL), air-drying at $\pm 25^{\circ} \mathrm{C}(K A)$ and fresh samples without drying as control. In the result of analysis with Kruskall-Wallis test show that the drying method of simplisia can influence significantly of percent inhibition extract methanol Pandanus amaryllifolius leaves against DPPH, the highest percent inhibition were by oven-drying of $64,553 \%$, then followed on samples dried with SML, SMTL, $K A$ and fresh samples respectively of 61,$73 ; 58,81 ; 56,14$ dan 55,13\%. Drying method of simplisia can influence antioxidant activity extract methanol Pandanus amaryllifolius, which the optimal drying for the samples were dried in oven
\end{abstract}

Key Words : Antioxidant, Pandanus amaryllifolius, drying methods, DPPH.

\begin{abstract}
ABSTRAK
Pengolahan pasca panen tanaman dapat menentukan kualitas bahan baku tanaman obat. Faktor utama yang sangat berperan dalam pengolahan pasca panen tanaman obat adalah proses pengeringan. Pengeringan merupakan tahapan penting dalam menjaga kestabilan senyawa dari simplisia terutama senyawa yang mempunyai aktivitas antioksidan. Tujuan dari penelitian ini yaitu untuk mengetahui pengaruh metode pengeringan simplisia terhadap aktivitas antioksidan ekstrak metanol daun pandan (Pandanus amaryllifolius). Metode pengeringan yang diuji adalah pengeringan oven pada suhu $40^{\circ} \mathrm{C}$, pengeringan sinar matahari langsung (SML), pengeringan sinar matahari tidak langsung (SMTL), pengeringan kering angin pada suhu $\pm 25^{\circ} \mathrm{C}$ (KA) serta sampel segar tanpa pengeringan sebagai kontrol. Hasil analisis menggunakan Uji Kruskall-Wallis menunjukkan bahwa metode pengeringan simplisia dapat berpengaruh secara signifikan pada persen inhibisi ekstrak metanol daun pandan terhadap DPPH, yang mana persen inhibisi tertinggi yaitu pada sampel yang dikeringkan dengan oven sebesar $64,55 \%$, kemudian diikuti pada sampel yang dikeringkan dengan SML, SMTL, KA dan segar masing-masing sebesar 61,73; 58,81; 56,14 dan 55,13\%. Metode pengeringan simplisia dapat mempengaruhi aktivitas antioksidan ekstrak metanol daun pandan (Pandanus amaryllifolius), dimana pengeringan yang optimal yaitu pada sampel yang dikeringkan dengan oven.
\end{abstract}

Kata Kunci : Antioksidan, daun pandan wangi, metode pengeringan, DPPH. 


\section{PENDAHULUAN}

Salah satu tahap penting pasca panen yang mempengaruhi kandungan senyawa berkhasiat adalah proses pengeringan (Mahapatraand Nguyen, 2009). Pengeringan bertujuan untuk menurunkan kandungan air dalam suatu simplisia. Pengeringan suatu bahan yang terlalu lama dan suhunya yang tinggi juga dapat menurunkan mutu karena dapat merusak komponen-komponen yang terdapat didalamnya (Hernani dan Nurdjanah, 2009). Kandungan senyawa fenolik dan flavonoid total dalam suatu simplisia yang mempunyai aktivitas antioksidan kestabilannya dapat dipengaruhi oleh proses pengeringan Hernani dan Nurdjanah,, 2009). Menurut Widyanto dan Nelistya proses pengeringan yang tidak tepat dapat menyebabkan penurunan aktivitas antioksidan (Widyantodan Nelistya, 2008).

Senyawa antioksidan merupakan senyawa yang kurang stabil dikarenakan mudah teroksidasinya senyawa antioksidan oleh lingkungan luar. Faktor yang mempengaruhi oksidasi yaitu seperti $\mathrm{pH}$, cahaya, oksigen, serta ion logam berat yang dapat berfungsi sebagai katalisator proses oksidasi (Simic et al, 1992). Sumber antioksidan alami banyak dijumpai pada tanaman yang mengandung senyawa fenolik yang dapat berupa golongan flavonoid, tokoferol dan asamasam polifungsional. Satu diantara tanaman di Indonesia yang terbukti mempunyai potensi aktivitas antioksidan yaitu daun pandan (Pandanus amaryllifolius). Berbagai hasil penelitian ekstrak daun pandan dilaporkan memiliki aktivitas sebagai antioksidan (Fatihanim dkk, 2008; Thatsanasuwan et al, 2015; Margaretta dkk, 2011). Hasil pemeriksaan menunjukkan bahwa daun pandan

Nera umilia purwanti dkk... mengandung senyawa alkaloid, flavonoid, saponin, tanin, polifenol, zat warna, kuersetin, karatenoid, tokoferol, tokotrienol dan minyak esensial (Miean \& Mohamed, 2001; Lee et al, 2004). Senyawa-senyawa seperti alkaloid, polifenol dan flavonoid tersebut mudah rusak oleh oksidasi.

Mengingat pentingnya proses pengeringan simplisia guna mendapatkan simplisia yang bermutu, maka di lakukan penelitian ini yang bertujuan untuk mengetahui sejauh mana pengaruh pengeringan simplisia dengan menggunakan 4 metode pengeringan yaitu pengeringan oven suhu $40^{\circ} \mathrm{C}$, sinar matahari langsung (SML), sinar matahari tidak langsung dengan kain hitam (SMTL) dan kering angin, serta salah satunya menggunakan sampel segar.

\section{METODE PENELITIAN}

\section{Bahan Tumbuhan}

Sampel tanaman yang digunakan pada penelitian ini adalah daun pandan yang diambil pada daerah Siantan di Jalan Budi Utomo, Kecamatan Pontianak Utara, Kabupaten Kota Pontianak.

\section{Bahan Kimia}

Larutan metanol p.a dan teknis, asam asetat anhidrat, akuades, larutan $\mathrm{FECl}_{3} 10 \%$, larutan $\mathrm{NaCl} 10 \%$, pereaksi Lieberman-Burchad $\left(\mathrm{CH}_{3} \mathrm{COOH}\right.$ glasial dan larutan $\mathrm{H}_{2} \mathrm{SO}_{4}$ ), pereaksi Dragendroff, peraksi Meyer, pereaksi Wagner, serbuk $\mathrm{Mg}$, larutan $\mathrm{H}_{2} \mathrm{SO}_{4} 2 \mathrm{~N}$, larutan $\mathrm{NaOH} 2$ $\mathrm{N}$, larutan $\mathrm{HCl} 2 \mathrm{~N}$, lempeng KLT silika gel $\mathrm{GF}_{254}$, dan serbuk DPPH.

Alat

Cawan krusibel (Pyrex), cawan penguap (Pyrex), bejana KLT (CAMAG), desikator (NORMAX), hot plate (Schott Instrument), lampu UV $366 \mathrm{~nm}$ dan 254 nm, mikropipet (Rainin E1019705K®), 
oven (Memmert), rotary evaporator (Heldolph tipe Hei-VAP), spektrofotometer UV-Vis (Shimadzu UV2450), timbangan analitik (Precisa TYP 320-9410-003) dan waterbath (Memmert tipe WNB-1314).

\section{Perlakuan Pengeringan}

Sampel dikeringkan dengan 4 metode pengeringan yaitu pengeringan oven suhu $40^{\circ} \mathrm{C}$, SML, SMTL, kering angin. Keempat bagian yang diperlakukan dengan pengeringan masing-masing hingga mencapai kadar air $<10 \%$ (Tsalies, 2004; Rivai dkk, 2010).

\section{Ekstraksi Sampel}

Metode ekstraksi yang digunakan dalam penelitian ini adalah maserasi. Proses ekstraksi dilakukan terhadap 5 sampel simplisia daun pandan. Simplisia ditimbang, dimasukkan ke dalam bejana maserasi dan ditambahkan pelarut metanol $80 \%$ sampai semua sampel terendam oleh pelarut lalu ditutup dengan aluminium foil. Maserasi dilakukan selama 3 hari, setiap 1x24 jam pelarut diganti dan dilakukan pengadukan tiga kali sehari. Hasil maserasi disaring untuk memisahkan filtrat dan residunya. Filtrat yang diperoleh dikumpulkan dan disaring. Kemudian ekstrak tersebut dipekatkan menggunakan rotary evaporator vacuum dan water bath pada suhu $40^{\circ} \mathrm{C}$ hingga pelarut menguap dan ekstrak menjadi lebih kental tetapi masih dapat dituang (Saifudin dkk, 2011).

\section{Skrining Fitokimia}

Kelima sampel ekstrak metanol daun pandan dilakukan identifikasi pada golongan senyawa steroid/ triterpenoid, alkaloid, flavonoid, fenolik, saponin dan tanin dengan menggunakan uji tabung( Harborne, 1987; Depkes, 1989; Hanani, 2015).

\section{Uji Pendahuluan Secara KLT}

Uji pendahuluan pada ekstrak metanol daun pandan sebagai penangkal radikal dilakukan sesuai metode Demirezer dkk dengan sedikit modifikasi pada fase gerak. Uji pendahuluan ini dengan cara kromatogram hasil KLT disemprot dengan larutan $0,2 \% \mathrm{DPPH}$ dalam metanol dan disemprot $\mathrm{FeCl}_{3}$ (Demirezer et al, 2001). Fase gerak yang digunakan setelah melakukan optimasi yaitu kloroform : metanol (9:1) dengan jarak elusi $8 \mathrm{~cm}$.

\section{Pengukuran Aktivitas Antioksidan}

Larutan sampel dengan konsentrasi 26 ppm yang telah dibuat tersebut dilakukan optimasi dengan mengambil dan ditambahkan larutan DPPH 26 ppm dengan perbandingan $1: 1$ (1 mL larutan sampel : $1 \mathrm{~mL}$ larutan DPPH $26 \mathrm{ppm}$ ). Campuran selanjutnya dikocok dan diinkubasi pada suhu kamar selama 30 menit di tempat gelap. Selanjutnya diukur absorbansinya pada panjang gelombang $515,80 \mathrm{~nm}$. Kemudian dihitung persen aktivitas antioksidannya (\% inhibisi) pada masing-masing sampel dengan 5 metode pengeringan simplisia. Perlakuan yang sama juga dilakukan untuk larutan blanko (larutan DPPH yang tidak mengandung bahan uji). Konsentrasi larutan blanko yang digunakan yaitu larutan DPPH 26 ppm . Zeroing awal menggunakan metanol p.a Nurliyana dkk, 2010).

Data hasil pengukuran absorbansi dianalisa persentase aktivitas antioksidannya menggunakan persamaan 5(Demirezer et al, 2001) :

$\%$ Inhibisi $=\frac{\text { Ablanko-Asampel }}{\text { Ablanko }} \times 100 \%$

Keterangan : $\mathrm{A}=$ Nilai absorbansi

\section{Analisis Hasil Pengolahan Data}


Data yang diperoleh dari penelitian ini berupa persen inhibisi yang selanjutnya dianalisis menggunakan SPSS Trial 21.

\section{Hasil dan Pembahasan}

\section{Hasil Proses Pengeringan Sampel dan Penetapan Kadar Air Simplisia}

Hasil proses pengeringan simplisia akan menurunkan bobot simplisia kering dari daun pandan. Simplisia dengan berat kering paling tinggi yaiu simplisia yang dikeringkan dengan oven pada suhu $40^{\circ} \mathrm{C}$ sebanyak 104,50 g, sedangkan simplisia dengan berat kering paling rendah yaitu simplisia yang dikeringkan dengan sinar matahari tidak langsung (dengan kain hitam) sebanyak 84,76 g. Penurunan bobot simplisia ini berkaitan dengan adanya proses penguapan air serta senyawa yang mudah menguap di dalam daun pandan yang terjadi selama proses pengeringan (Wiraguma dkk, 2010). Hasil proses pengeringan simplisia dapat dilihat pada tabel 1.

Tabel 1. Hasil Proses Pengeringan Simplisia

\begin{tabular}{llccc}
\hline No. & \multicolumn{1}{c}{$\begin{array}{c}\text { Metode } \\
\text { Pengeringan }\end{array}$} & $\begin{array}{c}\text { Bobot Simplisia } \\
\text { Basah }(\mathbf{g})\end{array}$ & $\begin{array}{c}\text { Bobot Simplisia } \\
\text { Kering }(\mathbf{g})\end{array}$ & $\begin{array}{c}\text { Lama Pengeringan } \\
(\text { Hari })\end{array}$ \\
\hline 1. & Oven & 600,03 & 104,50 & 15 \\
2. & SML & 600,06 & 97,47 & 26 \\
3. & SMTL & 600,09 & 84,76 & 30 \\
4. & Kering Angin & 600,04 & 92,76 & 65 \\
\hline
\end{tabular}

Kadar air simplisia daun pandan yang dikeringkan dengan 4 metode pengeringan yaitu antara 5,54 - 9,65\%, (tabel 2). Besarnya kadar air tersebut tidak melebihi standar yang ditentukan dalam
Farmakope Indonesia yang menyatakan bahwa kadar air standar pada suatu simplisia bahan obat yaitu sebesar $10 \%$ (Saifudin dkk, 2011).

Tabel 2. Penetapan Kadar Air Simplisia

\begin{tabular}{ll}
\hline Sampel Simplisia Kering & Kadar Air $(\%)$ \\
\hline Oven & $9,01 \pm 0,033$ \\
SML & $5,54 \pm 0,497$ \\
SMTL & $7,83 \pm 0,308$ \\
Kering Angin & $7,38 \pm 0,258$ \\
\hline
\end{tabular}

\section{Organoleptis}

Hasil keempat metode pengeringan simplisia mempengaruhi organoleptis daun pandan salah satunya pada warna.
Pengamatan secara visual menunjukkan bahwa terdapat perbedaan intensitas warna hijau pada daun pandan pada kelima sampel tersebut (gambar 1). 


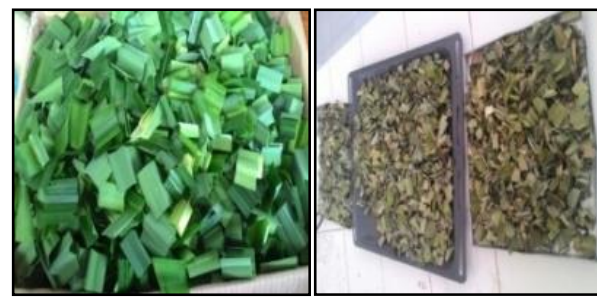

Segar

Oven

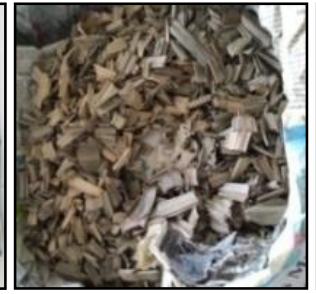

SML

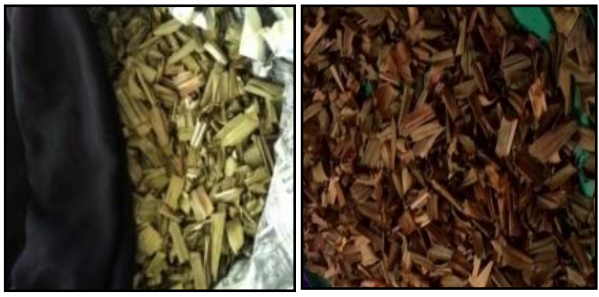

SMTL

KA
Berdasarkan gambar tersebut diperoleh hasil bahwa pada sampel segar daun masih berwarna hijau segar diikuti dengan sampel oven yang berwarna hijau muda yang mulai pudar serta sampel SMTL berwarna hijau kekuningan. Kemudian pada sampel SML warna daun yang dihasilkan berupa warna hijau mulai kecoklatan bila dibandingkan dengan sampel SMTL. Sedangkan pada sampel KA daun berwarna coklat kemerahan. Warna simplisia terlihat berbeda antara keempat perlakuakn pengeringan daun pandan. Perbedaan warna tersebut dikarenakan terjadinya proses degradasi klorofil dari daun pandan. Hasil ini menunjukkan bahwa terjadi proses degradasi pigmen klorofil. Hal ini sesuai dengan penelitian Sajilata dkk, 2006 dan Gross, 1991 yang menjelaskan bahwa perubahan warna pada pigmen menunjukkan terjadinya degradasi akibat terpapar pada cahaya degan intensitas tinggi dalam waktu yang cukup lama.

Hasil studi pada pengamatan secara visual menunjukkan bahwa semakin panjang waktu curing (pengeringan), mengakibatkan intensitas warna hijau daun pandan wangi berkurang dan intensitas warna coklat bertambah (Wiraguma dkk, 2010).

Pemucatan klorofil terjadi karena proses oksidasi yang melibatkan enzim seperti lipoksigenase, peroksidase dan oksidase (Gross, 1991). Perubahan warna daun menjadi coklat juga berkaitan dengan kandungan air pada daun yang melibatkan reaksi enzimatis. Semakin lama proses pengeringan yang terjadi, maka semakin lama pula air berada di dalam simplisia sehingga memungkinkan terjadinya reaksi degragadi klorofil menjadi feofitin akan semakin besar. Hal ini terlihat pada sampel yang dikeringkan dengan kering angin selama 65 hari yang berwarna lebih coklat bila dibandingkan dengan sampel lainnya.

Warna hijau pada daun pandan ini karena adanya kandungan klorofil. Klorofil adalah pigmen pemberi warna hijau pada tumbuhan, alga dan bakteri fotosintetik. Namun klorofil mudah mengalami degradasi menjadi turunannya. Klorofil sangat mudah terdegradasi oleh pengaruh suhu, cahaya, ph, oksigen dan alcohol (Gross, 1991).

\section{Ekstraksi Daun Pandan}

Kelima sampel diekstraksi dengan maserasi. Senyawa yang berperan memiliki aktivitas antioksidan pada daun pandan adalah golongan senyawa polifenol (Fatihanim dkk, 2001)

Hasil persen rendemen yang diperoleh pada kelima sampel ekstrak metanol daun pandan yaitu antara 12,05 $25,30 \%$. Persen rendemen tertinggi diperoleh pada sampel yang dikeringkan dengan metode pengeringan oven $40^{\circ} \mathrm{C}$ 
sebesar 25,30\%, sedangkan persen rendemen terendah diperoleh pada sampel daun segar sebesar $12,05 \%$. Hal ini sejalan dengan beberapa penelitian yang menyatakan bahwa pengeringan oven $40^{\circ}$
C dapat memberikan kadar ekstraktif tertinggi sedangkan sampel daun segar memberikan kadar ekstraktif terendah (Winardi, 2012; Rivai dkk, 2010). Hasil ekstraksi dapat dilihat pada tabel 3.

Tabel 3. Hasil Pengolahan dan Ekstraksi Daun Pandan

\begin{tabular}{llllll}
\hline Sampel & $\begin{array}{l}\text { Warna } \\
\text { Simplisia }\end{array}$ & Warna Ekstrak & $\begin{array}{l}\text { Berat } \\
\text { Simplisia }(\mathbf{g})\end{array}$ & $\begin{array}{l}\text { Berat } \\
\text { Ekstrak (g) }\end{array}$ & $\begin{array}{l}\text { \% } \\
\text { Rendemen }\end{array}$ \\
\hline Basah & Hijau Tua & $\begin{array}{l}\text { Hitam } \\
\text { Kehijauan }\end{array}$ & 600,01 & 72,31 & 12,05 \\
Oven & Hijau Muda & $\begin{array}{l}\text { Hitam } \\
\text { Kecoklatan }\end{array}$ & 104,50 & 26,44 & 25,30 \\
SML & Hijau & Hitam kehijauan & 97,47 & 24,43 & 25,06 \\
KMTL & $\begin{array}{l}\text { Hijau } \\
\text { Kecoklatan }\end{array}$ & Hitam kehijauan & 84,76 & 16,01 & 18,88 \\
KA & $\begin{array}{l}\text { Hijau } \\
\text { Kecoklatan }\end{array}$ & $\begin{array}{l}\text { Hitam } \\
\text { Kehijauan }\end{array}$ & 92,76 & 17,8 & 19,18 \\
& & &
\end{tabular}

\section{Skrining Fitokimia}

Tabel 4. Hasil Uji Skrining Fitokimia Ekstrak Metanol Daun Pandan

\begin{tabular}{|c|c|c|c|c|c|c|c|}
\hline \multirow{2}{*}{$\begin{array}{l}\text { Skrining } \\
\text { Fitokimia }\end{array}$} & \multirow{2}{*}{ Pereaksi } & \multirow{2}{*}{$\begin{array}{l}\text { Warna }(\mathbf{W}) / \\
\text { Endapan }(\mathbf{E})\end{array}$} & \multicolumn{5}{|c|}{ Hasil Uji } \\
\hline & & & Basah & Oven & SML & SMTL & KA \\
\hline \multirow{2}{*}{ Steroid/ Triterpen } & \multirow{2}{*}{$\begin{array}{l}\text { Lieberman- } \\
\text { Birchard }\end{array}$} & $\begin{array}{l}\text { Steroid } \\
\text { W. Biru }\end{array}$ & + & + & + & + & + \\
\hline & & $\begin{array}{l}\text { Triterpen } \\
\text { W. Merah }\end{array}$ & - & - & - & - & - \\
\hline \multirow{3}{*}{ Alkaloid } & Mayer & E. Putih & + & + & + & + & + \\
\hline & Dragendorff & E. Coklat & + & + & + & + & + \\
\hline & Wagner & Kemerahan & + & + & + & + & + \\
\hline Flavonoid & $\begin{array}{l}\text { Pita } \mathrm{Mg}+\mathrm{HCl} \\
\text { Pekat }\end{array}$ & W. Merah, Jingga & + & + & + & + & + \\
\hline Fenolik & $\mathrm{FeCl}_{3} 3 \%$ & $\begin{array}{l}\text { W. Hijau } \\
\text { Kehitaman }\end{array}$ & + & + & + & + & + \\
\hline Saponin & $\begin{array}{l}\text { Uji Forth } \\
\text { (+Akuades) }\end{array}$ & Berbuih & + & + & + & + & + \\
\hline \multirow{2}{*}{ Tanin } & $\begin{array}{l}\mathrm{NaCl} 10 \%+ \\
\text { Gelatin } 1 \%\end{array}$ & E. Putih & - & - & - & - & - \\
\hline & $\mathrm{FeCl}_{3} 3 \%$ & $\begin{array}{l}\text { W. Hijau } \\
\text { Kehitaman }\end{array}$ & + & + & + & + & + \\
\hline
\end{tabular}


Hasil pengujian menunjukkan kelima sampel ekstrak metanol daun pandan mengandung senyawa golongan steroid, alkaloid, flavonoid, fenolik dan saponin (tabel 4). Hal ini sesuai dengan beberapa penelitian mengenai skrining fitokimia ekstrak daun pandan yang menyatakan bahwa daun pandan mengandung steroid, alkaloid, flavonoid, fenolik dan saponin (Ismayati dkk, 2015; Gopalkrishnan et al, 2015).

\section{Uji Pendahuluan dengan KLT}

Uji pendahuluan dengan KLT terhadap kelima sampel ekstrak metanol daun pandan dilakukan untuk melihat pola kromatogram dari ekstrak tersebut. Hasil elusi dideteksi dengan detektor sinar UV pada panjang gelombang 254 dan $366 \mathrm{~nm}$ untuk melihat pola kromatogram. Penampak bercak yang digunakan untuk senyawa fenolik adalah $\mathrm{FeCl}_{3} \quad 3 \%$ dan larutan DPPH 0,2 \% untuk melihat aktivitas antioksidan.

Hasil pola kromatogram yang di peroleh pada kelima sampel ekstrak metanol daun pandan tersebut tidak berbeda secara visual, yang artinya pola kromatogram dari kelima sampel tersebut sama. Sehingga dapat dikatakan bahwa pengeringan simplisia tidak mempengaruhi pola kromatogram dari kelima sampel ekstrak metanol daun pandan tersebut. Hasil uji KLT kelima ekstrak metanol daun pandan dapat dilihat pada gambar 2.

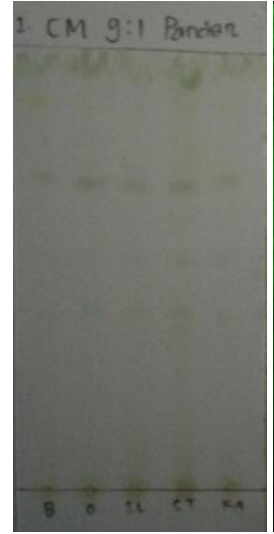

$\mathbf{a}$

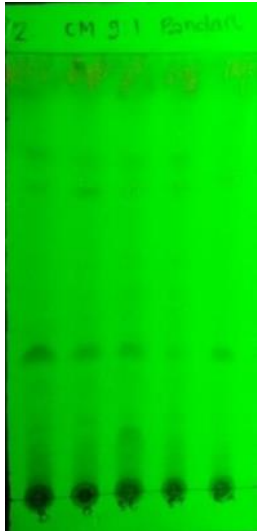

b

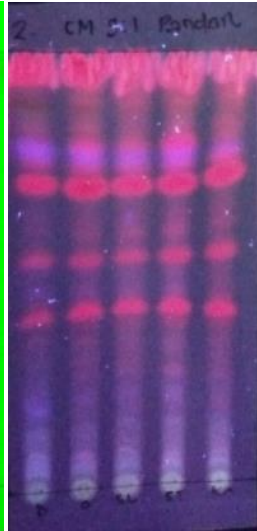

c

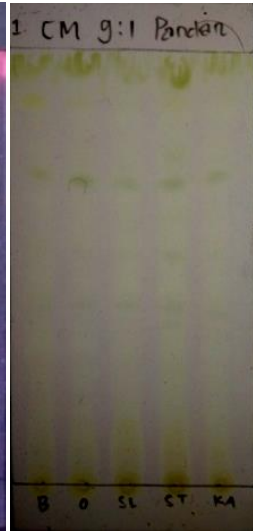

d

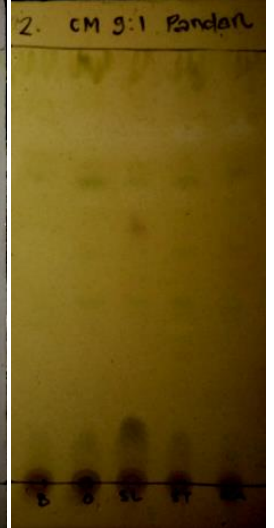

e

\section{Gambar 2. Hasil Uji KLT Kelima Sampel Ekstrak}

Keterangan :

a. Hasil pengamatan secara visual

b. Hasil pengamatan pada panjang gelombang $254 \mathrm{~nm}$

c. Hasil pengamatan pada panjang gelombang $366 \mathrm{~nm}$

d. Plat KLT setelah disemprot DPPH 0,2\%

e. Plat KLT setelah disemprot pereaksi $\mathrm{FeCl}_{3} 3 \%$

\section{Hasil Uji Aktivitas Antioksidan Ekstrak Metanol Daun Pandan dengan Metode DPPH}

Uji aktivitas antioksidan kelima sampel ekstrak metanol daun pandan dilakukan secara kuantitatif terhadap DPPH dengan menghitung \%inhibisi (gambar 3). 


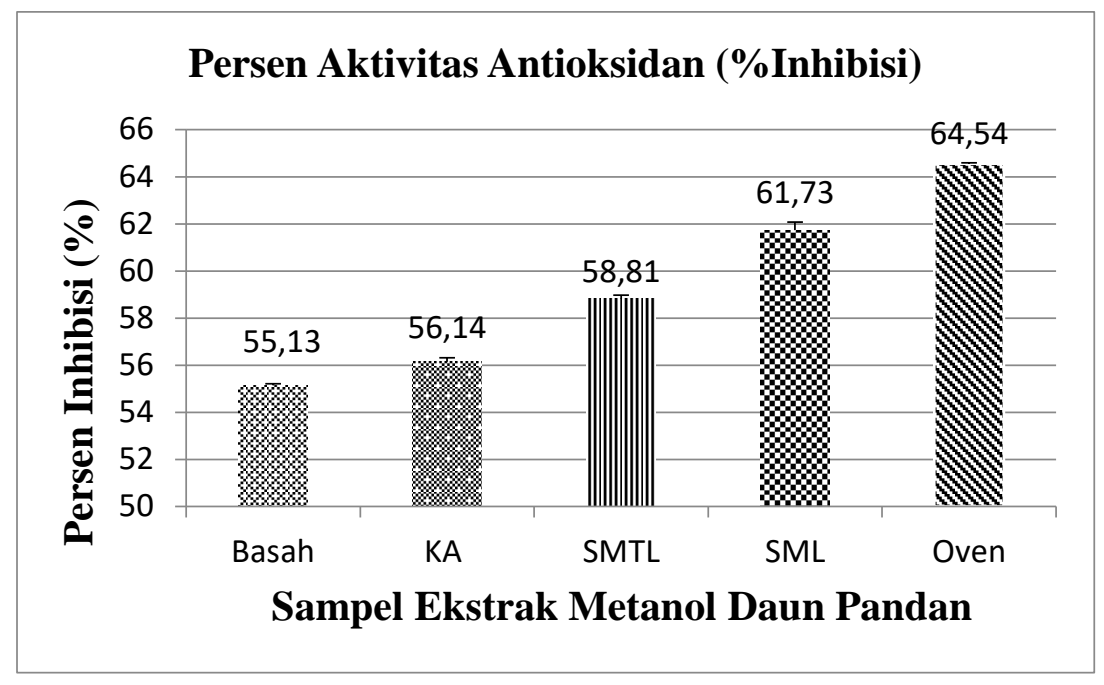

\section{Gambar 3. Grafik Persen Aktivitas Antioksidan Kelima Sampel Ekstrak Metanol Daun Pandan}

\begin{abstract}
Hasil penelitian menunjukkan bahwa aktivitas antioksidan tertinggi terdapat pada metode pengeringan oven pada suhu $40^{\circ} \mathrm{C}$ dengan lama pengeringan 15 hari dengan persen aktivitas antioksidan sebesar 64,54\%. Sedangkan aktivitas antioksidan terendah terdapat pada sampel basah tanpa pengeringan dengan persen aktivitas antioksidan sebesar $55,13 \%$. Berdasarkan hasil tersebut dapat disimpulkan bahwa semua metode pengeringan simplisia daun pandan mengalami penurunan aktivitas antioksidan seiring dengan lamanya waktu pengeringan.
\end{abstract}

Pengeringan daun pandan dengan oven pada suhu $40^{\circ} \mathrm{C}$ adalah cara pengeringan yang optimum untuk mendapatkan kadar senyawa fenolat yang tertinggi, dimana hal ini merujuk pada penelitian Harrizul Rivai dkk 2011 (Rivai dkk, 2010). Pada gambar 3 juga memperlihatkan bahwa pengeringan dengan kering-angin memakan waktu yang lama (65 hari) sehingga dikhawatirkan terjadinya penguraian senyawa fenolat oleh bantuan enzim fenolase yang terdapat

Nera umilia purwanti dkk... dalam tumbuhan (Rivai dkk, 2010). Hal ini terlihat dari persen aktivitas antioksidan yang lebih rendah pada pengeringan kering-angin suhu $\pm 25^{\circ} \mathrm{C}$ yaitu sebesar $56,14 \%$ daripada pengeringan oven pada suhu $40^{\circ} \mathrm{C}$ yang hanya memakan waktu 15 hari.

Namun demikian, pada sampel yang tidak mengalami pengeringan (sampel segar) juga mengalami penurunan persen inhibisi paling besar dibandingkan menggunakan metode pengeringan kering angin. Hal ini dapat dikarenakan oleh berbagai faktor diantaranya adalah sifat yang mudah rusak bila terpapar oksigen, cahaya, suhu, proses pasca panen serta proses ekstraksi (Molyneux, 2004). Selama proses pengeringan terjadi penguapan air yang mengakibatkan bahan mengalami kerusakan sel sebagai akibat lepasnya air. Kerusakan sel tersebut mendorong mudahnya senyawa metabolit untuk dapat diekstrak pada simplisia yang dikeringkan dibandingkan dengan simplisia segar (Winardi, 2012;Depkes, 1986).

\section{Analisis Data}


Analisis data kelima sampel ekstrak metanol daun pandan digunakan untuk menguji hipotesis, menggunakan SPSS trial 21. Hasil uji Kruskal-Wallis menunjukkan nilai p-value pada data \%inhibisi yaitu 0,009 sehingga nilai $\mathrm{p}<0,05$ yang artinya terdapat perbedaan bermakna antar kelompok. Hal ini berarti bahwa dengan adanya perbedaan metode pengeringan simplisia pada daun pandan dapat mempengaruhi aktivitas antioksidan berupa \%inhibisi yang dihasilkan

\section{DAFTAR PUSTAKA}

Demirezer, L.O., Kruuzum-Uz., Bergere, I., Swhiewe, H.J., dan Zeeck, A., 2001, The structures of antioxidant and cytotoxic agents from natural source: antraquinones and tannin from roots of Rumex patiential, Phytochemistry, 58, 1213-1217.

Departemen Kesehatan Republik Indonesia., 1989, Materia Medika Indonesia. Edisi V, Jakarta, Departemen Kesehatan Republik Indonesia.

Departemen Kesehatan Republik Indonesia., 1986, Sediaan Galenik, Jakarta, Departemen Kesehatan Republik Indonesia, 10-11.

Fatihanim, M.N., Suhaila, M., Nor, A.I., and Razali, I., 2008, Antioxidative properties of Pandanus amaryllifolius leaf extracts in accelerated oxidation and deep frying studies, Food Chemistry, 110(2), 319-327.

Gopalkrishnan, B., Agashe, S., and Kumavat, U., 2015, Pharmacognostical screening of flavouring leaves Pandanus amaryllifolius Rox, International Journal of Pharmacognosy and Phytochemical ResearchI, 7(4), 745-749, ISSN: 0975-4873.

\section{KESIMPULAN}

Metode pengeringan simplisia dapat berpengaruh secara signifikan terhadap \%inhibisi daun Pandanus amaryllifolius yang dihasilkan. Hasil \%inhibisi tertinggi yaitu pada sampel yang dikeringkan dengan oven dengan rata-rata \%Inhibisi sebesar 64,54\%, kemudian diikuti pada sampel yang dikeringkan dengan SML, SMTL, KA dan segar masing-masing sebesar 61,$73 ; 58,81$; 56,14 dan 55,13\%.

Gross, J., 1991, Pigments in Vegetables. An Avi Book, Van Nostrand Reinhold, New York, p.3-13.

Hanani, E., 2015, Analisis Fitokimia, Jakarta, EGC.

Hernani dan Nurdjanah,R., 2009, Aspek pengeringan dalam mempertahankan kandungan metabolit sekunder pada tanaman obat., Perkembangan Teknologi Tro, Vol 21 (2), 33-39.

Harborne, J.B., 1987, Metode Fitokimia, Bandung, ITB.

Ismayati, N., Mardiyaningsing, A., dan Trilestari., 2015, Aktivitas sitotoksis ekstrak etanolik dan fraksi dari ekstrak etanolik daun pandan (Pandanus amaryllifolius ROXB) terhadap sel kanker payudara MCF-7, The $2^{\text {nd }}$ University Research Coloquium, ISSN: 2407-9189.

Lee, B.L., Su, J., Ong, C.N., 2004, Monomeric C18 chromatographic method for the liquid chromatographic determination of lipophilic antioxidants plants, J. Chromatograp. A, 1048, 263-267.

Mahapatra, A.K., and C.N Nguyen., 2009, Drying of medicinal plants., ISHS Acta Horticulturae 756: International Symposium on Medicinal and Nutraceutical Plants.

Margaretta, S., Handayani, S.D., Indraswati, N., dan Hindarso, H., 
2011, Ekstraksi senyawa Phenolic Pandanus amaryllifolius Roxb. sebagai antioksidan alami, Widya Teknik, 10(1), 21-30.

Miean, K.H., Mohamed, S., 2001, Flavonoid (myricetin, quercetin, kaempferol, luteolin, and apigenin) content of edible tropical plants, J. Agr. Food Chem, 49, 3106-3112.

Molyneux, P., 2004, The use of the stable free radical diphenylpicrylhydrazyl (DPPH) for estimating antioxidant activity, J Sci Technol, 26(2), 211219.

Nurliyana, R., Syed, Z.I., Mustapha, S.K., Aisyah, M.R., dan Kamarul, R.K., 2010, Antioxidant study of pulp and peel dragon fruits: a comparative study, Int. Food Res. $J, 17,365-375$.

Rivai, H., Nurdin, H., Suyani, H., dan Bakhtiar,A., 2010, Pengaruh cara pengeringan terhadap perolehan ekstraktif, kadar senyawa fenolat dan aktivitas antioksidan dari Daun Dewa (Gynura pseudochina (L.) DC.), Majalah Obat Tradisional, 15(1), 26-33.

Saifudin, A., Rahayu, V., dan Teruna, H.W., 2011, Standarisasi Bahan Obat Alam, Jakarta, Graha Ilmu.

Sajilata \& Singhai., 2006, Isolation and stabilitation of natural pigments for food application, Stewart Postharvest Review, 5-11.

Simic, M.G., S.V Jovanovic \& E. Niki., 1992, Mechanisms of lipid oxidative processes and their inhibition. In: Angelo, A.J. (ed.), Lipid oxidation in Foods. Washington, American Chemical Society.

Thatsanasuwan, N., Srichamnong, W., Chupeerach, C., Kriengsinyos, W., and Suttisansanee, U., 2015, Antioxidant activities of Pandanus amaryllifolius leaves extracted under four designed extraction conditions, Food and Applied Bioscience Journal, 3 (2), 130-136.
Tsalies, C., 2004, Pengaruh Juvenil Hormon yang berasal dari ekstrak daun Pandan Wangi (Pandanus amarillyfolius, Roxb) terhadap perkembangan stadia pradewasa Nyamuk Aedes aegypti L, Skripsi, Bogor, Institut Pertanian Bogor.

Widyanto, P.S.,. dan A. Nelistya., 2008, Rosella: Aneka olahan, khasiat dan ramuan, Jakarta, Penebar Swadaya.

Winardi, R.R., 2012, Pengaruh metode pengeringan terhadap perolehan ekstraktif, alkaloid, dan flavonoid dari Daun Afrika (Aspilia africana C.D Adam), STEVIA, 2(1). ISSN: 2087-6939.

Wiraguma, I.G.N.P., Wartini, N.M., dan Yoga, G.S., Pengaruh metode dan lama curing terhadap karakteritik daun pandan wangi (Pandanus amaryllifolius Roxb.), Jurnal Fakultas Teknologi Pertanian Universitas Udayama. 